\title{
NEW CHALLENGES FOR THE INTERNATIONALIZATION OF FIRMS. ITALIAN COMPANIES IN CHINA: BUSINESS MODELS AND MARKET POLICIES
}

\author{
Elena Cedrola, University of Macerata, Italy \\ Loretta Battaglia, Catholic University of Milan, Italy \\ Chiara Cantù, Catholic University of Milan, Italy \\ Laura Gavinelli, University of Milan Bicocca, Italy \\ Alessandra Tzannis, Catholic University of Milan, Italy
}

\begin{abstract}
The emergence of markets such as China opens new opportunities in the internationalization process. For companies, especially for small and medium sized enterprises, the international context is a challenge to be faced by mobilizing and sharing the resources and knowledge of other players. This is subject to establishing strategic relations, in both the internal and foreign markets, which affect the entire corporate supply chain.

This theme was investigated by means of a study of a sample of companies operating in or for the Chinese market. The work provides managerial implications based on an evolutionary model to understand firm behavior in international markets.
\end{abstract}

\section{INTRODUCTION}

Changes in the national and international economic context and the opening of markets has guided the activities not of only large firms, but also those of small and medium-sized enterprises, beyond national borders. New opportunities and challenges have emerged from this global scenario and especially the need for a new approach to markets, no longer based on the traditional competition logic (Harold et al., 2000).

Numerous theories and empirical researches have been suggested in an attempt to delineate the internationalization processes and identify suitable methods and models. What emerges is that, while economic theory has investigated the determinants of these processes for some time now, in an attempt to determine the reasons and underlying motivations of trade between countries, there is still a remarkable diversity in the contributions and a fundamental lack of a common and shared foundation especially as concerns SMEs (Melin, 1992). In fact, there is no form of modeling that has offered specific support for this category of firms (Etemad, 2004). The majority of studies have focused on larger enterprises and on multinational companies, often in specific countries (Zwart, Gankema, 1990). As a result, traditional theories applied to different situations and dimensions are associated to the internationalization process of SMEs.

In particular, classic theory on internationalization describes commercial exchanges as a source of comparative advantages among parties (Smith, 1776; Ricardo, 1817) in terms of production factors (Olhin, 1933), technological innovations (Posner, 1961), intangible assets (Linder, 1961) or the presence of specific advantages (compared to competitors, advantages of internationalization, advantages of location) that are able to guide direct foreign investments (Hymer, 1976; Dunning, 1988).

In most subsequent theoretical contributions instead, internationalization is seen as a process of progressive and incremental development in terms of both risk and investment and entrepreneurial involvement. Specifically, for SMEs this path seems to be linked to the type and quantity of resources available in terms of innovation, know-how, technology, etc. (Leonidou, Katsikeas, 1996). Precisely because of progressive international involvement, the internationalization of enterprises is described as a multidimensional concept composed of operational, market, product, and time and performance variables. The strategic choices are instead influenced by factors such as economies of experience, information needs, the selection of entry methods, the effects of cultural distance, etc. According to this perspective, the adoption of international openness by SMEs is only subsequent to the achievement of a solid and competitive position in their own market. International expansion is thus understood as a means and strategy of growth (Cavusgil, 1980; Ruzzier, Antoncic, Hisrich, 2007).

A matter of particular importance for firms in international contexts is the cultural distance between the parties. The cultural aspects to consider for a correct approach to the markets concern the individual factors of the participants, the cultural dimensions of the specific firm and the national cultural factors to which the firm belongs (Kostova, Zaheer, 1999; Usunier, 1996; Ghauri, Usunier, 2003). They reflect the way in which people express themselves in terms of symbols, views on time and considerations on space and related dimensions (Usunier, Lee, 2005). Culture also permeates all the elements of the marketing mix and the validity of these elements must be assessed in the specific cultural context, both in B2B and B2C markets (De Burca, Fletcher, Brown, 2004). 
In support of the effects of cultural distance, international literature often stresses that companies first approach the internationalization process towards countries that are perceived as culturally near, before venturing into countries perceived as more distant (which could be China), in order to reduce the level of uncertainty (Johanson, Vahlne, 1992). This is why firms often tend to export to seemingly similar countries. A consequence is that products are exported in the same way as they are distributed on the national market, without making the adjustments required (O’Grady, 1996).

Further contributions highlight how the traditional Italian industrial structure, with a host of mainly family-based SMEs, establishes internationalization based on artisan experience and production specialization (Cedrola, 2005). More specifically, research and scientific production in the Italian context can be grouped into several macro areas:

- local district production systems and networks and internationalization processes (Rullani, 2006; Musso, 2006; Chiarvesio, Di Maria, 2009)

- $\quad$ analysis of competitive factors determining international openness (Varaldo, Ferrucci, 1997; Caroli, Lipparini, 2002; Marcone 2005)

- the relationship between ownership structure and access to foreign markets (Becchetti, Gonzales, 2001; Gallo et al., 2002)

- $\quad$ age and size in foreign development (Bonaccorsi 1992; Ferragina, Quintieri, 2001)

- characteristics of the governance system and internationalization processes (Compagno, 2003)

- $\quad$ entry method, Italian SME internationalization strategies and models (Mariotti, Mutinelli, 2001; Bontempi, Prodi, 2009; Zanni, Zucchella, 2009)

- $\quad$ subjects, relations and international management of the value chain (Pepe, Musso, 2009; Cerutti, Delbufalo, 2009; Belussi, Samara, Sedita, 2009).

Other scholars (e.g. Rullani, 2002, Cantù, Gavinelli, 2009) highlight how the territory is a vital resource because its own infrastructure, human resources and tax concessions support local development. In particular, Garofoli (2003) focuses on resources based on social relations and on the cultural environment. A key role is thus recognized to social relations, which affect the entry procedures to international markets, as the drivers of the development of interconnections between the various areas, support for the development of knowledge and reducing the risk and uncertainty of international markets. In light of this, commercial and production internationalization depends on the ability of firms to adapt to the context in which they operate and gradual learn in terms of experiential knowledge (Eriksson, Johansson, Majkgård, 1997). The aim is to reduce the information gap on international markets and become familiar with the conditions in the host country (Hostende 1980).

Finally, a growing number of contributions argue that Italian firms should rely on the exploitation of existing market relations (personal or interorganizational) between firms involved in the production, distribution and use of goods and services within an industrial system. According to these contributions, firms establish and cultivate relations with partners belonging to foreign networks to overcome their own limitations. In so doing, they influence and guide the internationalization process (Madhok, 1997; Cedrola, 2006; Cedrola, Cantù, Gavinelli, 2009). The collaborative and network approach should therefore be adopted to link the various actors involved in the production and commercialization processes of a product and/or service. This helps to redefine the value chain and to achieve profitable results in international markets. With these premises, the network becomes an instrument of governance (Belussi, 2007) able to manage cooperation between firms with various resources, skills and heterogeneity towards learning by interacting processes (Belussi, Pilotti, 2006; Zucchella, 2006).

\section{RESEARCH OBJECTIVES AND METHODOLOGY}

This paper proposes describing how Italian firms approach the Chinese market and in particular, how they have changed their business model to face the challenges presented by this market. The collaboration and cooperation arrangements existing between the actors along the business value chain is the focus of the analysis. The results are based on qualitative research that investigated a sample of 31 Italian firms operating in different industrial sectors. In-depth interviews were carried out with managers with various business functions such as CEOs, marketing managers and export managers.

The interviews began in the second quarter of 2009 and focused on the following issues:

- the company characteristics and business models (origin and evolution of the firm, organizational structure and offer);

- $\quad$ decision-making strategies and processes for the Chinese market; 
- collaborative relations along the business value chain (the actors involved and their role, activities carried out, resources used, types of relations);

- $\quad$ competences required, or those to be developed, to successfully operate in China.

The outline of the interview was sent via email prior to interviewing the companies involved in the research. A short report follows on the characteristics of the 31 companies investigated and the particularities of their operations in China. Subsequently the companies are positioned in an interpretative model proposed for the analysis of firm behavior in the Chinese market, together with a critical analysis of their positioning.

\section{RESULTS AND FUTURE PERSPECTIVES}

The evidence relating to 31 large, medium and small-size companies operating for and/or in the Chinese market is presented herewith following. Table 1 summarizes for each company investigated the industry of belonging, the size characteristics of the company, the strengths, the number of years in China, and the current for entry modes. The synthesis advances clarification of the orientation to the Chinese market, considering both the behavioral approach to international markets and the theme of trust and collaboration, and the strategic approach to the market in terms of strategy and marketing mix localization.

The analysis has allowed us to validate an interpretative model to understand the behavior of firms beyond national borders (Battaglia, Cedrola, 2010). This model is shown in Figure 1, the abscissa illustrates the strategic development of internationalization, the vertical axis represents the managerial evolution of companies towards the market while the Z-axis illustrates the product and process innovations of the companies themselves.

Describing the $\mathrm{X}$-axis from origin, in first place are enterprises with an opportunistic approach to the market. This implies the sale of excess-production across the border, the occasional satisfaction of requests coming from outside and the search for pure production efficiency. Continuing along the $\mathrm{X}$-axis are companies that follow a tailor-made approach, they create a totally new or modified product in accordance with the demands of each single customer. The operational logic, mainly based on manufacturing, foresees the implementation of product specifications dictated by or agreed with the customer. Contracts or commissioned projects are included in this context. Often these two approaches correspond to the initial internationalization methods of firms that do not yet present themselves strategically to the markets. In fact, in this area are both firms in search of savings and low-cost efficiency, and firms with production capacity that try to exploit a new and very promising emerging market. For example, companies falling into this category are "made in Italy" firms that exploit sales opportunities tout court across the border. Other companies in the "specialization" area have completely changed their business behavior according to two approaches. One is the niche approach, having as a reference model the "German hidden champions", defined as small, highly competitive, little-known firms operating in niche markets at world level (Simon, 1996). The other approach focuses on drivers such as design, specialization and technological leadership. Falling into this group are "Made in Italy" companies that address the markets strategically, operating, for example, on the basis of a strong brand or consolidated their technological or country image.

A further group of firms defines and adapts their offer according to the market of destination, in addition to having their own consolidated expertise in the specialization area (localization approach). This implies total or partial modifications of their marketing mix (product, communication and service), as well as the way to do business (organization, management of resources, work method, temporal distribution of activities and processes), in order to meet the specific cultural differences of the countries or markets. The localization of the marketing mix and the resulting adaptation of internal businesses processes are not sufficient to ensure the sustainability of the business and the synchronization between supply and market at international level. Thus, the behavior of firms towards the markets and the firm culture also assume importance. These two variables, indicated on the Y-axis, show the tendency of the company to work autonomously or in collaboration with other national or international subjects belonging, or not, to the production chain. The position on this axis expresses the pervasiveness of collaboration on a production/export level in the case of districts and consortia, and on a strategic cooperation and partnership level in the case of networks. The willingness to cooperate leads to the themes of trust and firm culture: an entrepreneur who does not delegate will not readily collaborate in an attempt to seize opportunities. In this case, the negotiation strategy is distributive, leading to a "win-lose" type logic where the tension is focused on maximizing individual or business objectives. Information exchange will be minimal and related only to essential data, since the objective is the collection of the greatest amount of information possible from the counterparty (Ghauri, Usunier, 2003).

The interpretative model proposed is the starting point to position the firms investigated on the axes (Fig. 2). 
Quadrant D of the matrix includes firms that best interpret the relationship with the Chinese market, expressing a balance between product-process-market and relations with the Chinese system. The top part of the quadrant highlights the companies $[4,1,12,14,31]$ that have invested strategically in the Chinese market mainly in the wake of their international customers but simultaneously developing Chinese customers. All have introduced highly innovative products and processes into China, also developing less technologically advanced products suitable for the local market (developing) and some international markets. Elements that unite the firms in this cluster are: in situ production (with WFOE structures) mostly for the Chinese market and intense relations developed with suppliers, distributors and customers, and with institutions and government agencies. The four companies operate in the automotive supplier market as OEM suppliers (original equipment manufacturer) of Chinese and international brands. Some of these also operate in the after market providing [4] a pre and post sales assistance service through a dedicated assistance network.

On the left side of quadrant $\mathrm{D}$ are firms that, although having established relations on the territory for the management of the business, give priority in their operations to the specialization component, be it technical, product or image related. These companies belong to very heterogeneous sectors (from electronics, to valves, to automation) and generally favor the technological dimension. Only one company [2] is in the traditional "Made in Italy" sector, namely, the shoe industry. All the other companies in the "Made in Italy" sector investigated instead are positioned in other areas of the matrix, highlighting a minor adjustment of the marketing mix, limited partnerships, lesser proximity to the markets and, often, a significant degree of self-reference. Returning to discuss the features of companies in the left part of quadrant $\mathrm{D}$, we note that collaborations and relations have become an integral part of their operations in China in order to adapt their innovations to the particularities of the market. At the same time, we note the critical issue of the protection of know-how that explains the location of many companies in the lower part of the quadrant. Here we find companies operating in Chinese JVs, often with minority shares, which do not predominate over the relationship with the company (internal) and with the market.

Firms that instead have the greatest difficulty in establishing direct managerial figures (Italian or Chinese) in Chinese organizational units and that are still based on the "trusted individual" are in the cluster closest to the centre of the matrix. Critical in this case is distribution management, all too often dependent on only a few individuals, although trusted, and of local origin.

When turning our attention to the lower quadrant (C), companies belonging to different sectors marked by high levels of specialization that do not yet consider it opportune to invest in relations and collaborations are also evidenced. The reasons may be their recent approach to the Chinese market [26,3], or the marked self-reference linked to the strength of the brand [17] or, above all, an enterprise culture anchored to the figure of the entrepreneurial group and to the district of belonging with its relative manufacturing culture.

Preceding this position is the tailor-made area, which includes companies operating entirely on commissions, leaving room for a minimum level of cooperation, especially with customers and with the local labour force. The relations in this case are targeted and superficial, since they are not load-bearing elements of the business model.

Finally, in the vicinity of the ordinate axis - the opportunistic approach - three firms are located $(11,15,25)$ : the first two belong to the food sector and the third to the metallurgical sector. Collaborations in these cases were put in place with some distributors and local caterers or, occasionally, with the Italian Institute for Foreign Trade and the Chamber of Commerce (missions of Italian firms in China). Or again with Chinese private or state partners for the implementation of JVs that after a satisfactory initial takeoff (around 30 years ago) have declined, relinquishing their presence in China as purely opportunistic.

\section{CONCLUSION}

The empirical analysis shows that the Italian firms investigated demonstrate increasingly proactive behavior towards international markets in agreement with that highlighted by the most recent developments in both national and international literature on the theme of foreign market strategies. Furthermore, the analysis shows a change in the attitude of enterprises, particularly in terms of geographically distant countries such as China: smaller companies also tend to listen to and understand the markets of interest, getting closer to the local culture, adapting to it and therefore adapting their own businesses not only in terms of their internal structure but also all the marketing mix levers, often thanks to the support of the strategic actors in situ. These adjustments and behaviors although often geared to regulatory, bureaucratic or protective type needs or to the target markets, is however pushing firms to endow themselves with new resources and structures compared to their historic roots and firm culture. 
The results of the analysis confirm the importance of collaborations between the various actors located in China and their key role for the success of many activities along the value chain. Business relations become a key element to investigate the needs of foreign customers, to recognize the dynamics of the international context and to identify business partners. Both horizontal and vertical (intra-organizational) relations become critical. Horizontal relations are established between similar businesses in the area (such as Italian companies located in the region, etc.) and also between the corresponding levels of the hierarchy of companies and institutions, in particular in countries characterized by a greater distance from power (Hofstede, 2001; Herbig 2003). Vertical relations should be developed along the value chain, thus between the suppliers of raw materials, suppliers of services, customer or distributors and the holders of institutional power. These relations should be defined at all levels. Inter-organizational relations on all levels of the firm also prove relevant. To manage the complex relationships indicated above requires having a well-trained team prepared to face and deal with the counterparties of distant cultures in order to achieve sustainable development over time.

In short, the adaptation of a company and its products to the needs, values and expectations of a distant country (geographically and culturally) requires the implementation of a path that involves all the processes (decision-making, management, organizational and marketing) and all the people that work directly or indirectly with foreign countries, on the different levels of hierarchy, irrespective of firm size (Cedrola, Battaglia and Tzannis, 2009).

To operate in China, cutting edge technology and a quality product or strong brand, are often a necessary but not sufficient condition, especially when aiming for a significant and continuous presence over time. It is indispensable for companies, even smaller firms, to work on relations on all levels of the supply chain and with the bearers of local interest, whether government agencies, universities, customs organizations or partners at different levels. These relations also favor the development of trust between operators, not to be construed as unconditional trust, but as a willingness to understand each other, to share, to work together towards a common long-term goal.

Finally, the interviews revealed that the positions of excellence reached by companies [quadrant D] are the result of an evolutionary path independent of the market entry strategy. The firms that interpret the Chinese market from a strategic perspective have progressively worked towards involving China and the Chinese, moving from simple methods - individual commercial relations, representative agencies, etc. - to more demanding methods both in terms of economic and relational investments such as joint ventures and direct investments (WFOE) through acquisitions or green fields. This is the receipe of Italian best practice in China. They evolved their business model centered on the Italian market and on the Italian needs to a new model focused at the meantime on:

- specialization

- knowledge of the market and localization of the marketing mix

- relationships along the whole supply chain

- involvement of the local actors in the process of innovation and production.

The influence of the new management model can be measured in the increasing of the revenue and market share in China, the reduction of the turnover of the employees, the strengthening of local and national relationships. So this firms operate in China with Chinese managers and employees, not only to reduce the production costs, in order to better satisfy consumer and client needs.

The research on the internationalization of Italian enterprises in China will not only be dedicated to bridging some of the gaps of this current work, namely the representative extension of the analysis to all sectors and geographical areas but also to broaden the analysis of the results obtained. 


\section{TABLES}

Table 1: The main characteristics of the 31 enterprises operating in China

\begin{tabular}{|c|c|c|c|c|c|c|}
\hline $\mathrm{N}^{0}$ & Industry & $\begin{array}{l}\begin{array}{l}\text { Tumover } \\
\text { (mill. }\end{array} \\
\end{array}$ & $\begin{array}{l}\text { Numberof } \\
\text { employees }\end{array}$ & Strengths & $\begin{array}{l}\text { Years in } \\
\text { China }\end{array}$ & $\begin{array}{l}\text { Current procedures forthe } \\
\text { entry in China }\end{array}$ \\
\hline 1 & $\begin{array}{l}\text { Electronics (security } \\
\text { systems) }\end{array}$ & 116 & 700 & $\begin{array}{l}\text { Product, process and market } \\
\text { innovation }\end{array}$ & 15 & WFOE (research and production) \\
\hline 2 & Shoe manufac turing & 57 & 100 & $\begin{array}{l}\text { Relations with suppliers and } \\
\text { distributors }\end{array}$ & 4 & $\begin{array}{l}\text { Directexports through distributors } \\
\text { and multi-brand stores }\end{array}$ \\
\hline 3 & $\begin{array}{l}\text { Engineering (machines to } \\
\text { fill extinguishers) }\end{array}$ & 2 & 6 & $\begin{array}{l}\text { Product quality, technological } \\
\text { reputation }\end{array}$ & 2 & $\begin{array}{l}\text { Direct exports through exclusive } \\
\text { agent }\end{array}$ \\
\hline 4 & $\begin{array}{l}\text { Ecologic al batteries and } \\
\text { cars }\end{array}$ & 60 & 300 & $\begin{array}{l}\text { Product quality -technological } \\
\text { development-pre and postsales } \\
\text { service }\end{array}$ & 15 & WFOE +JV \\
\hline 5 & $\begin{array}{l}\text { Oiland gas transport } \\
\text { casings + thermal insulation }\end{array}$ & 350 & 2000 & $\begin{array}{l}\text { Commercial synergies - product } \\
\text { quality and reliability }\end{array}$ & 17 & JV \\
\hline 6 & $\begin{array}{l}\text { Automation (parking and } \\
\text { automatic elevators) }\end{array}$ & 225 & 150 & $\begin{array}{l}\text { Quality -technology - Know- how- } \\
\text { services }\end{array}$ & 2 & Subsidiary \\
\hline 7 & $\begin{array}{l}\text { Engineering (control } \\
\text { systems and valves) }\end{array}$ & 24 & 160 & $\begin{array}{l}\text { Product quality, pre and postsales } \\
\text { assistance }\end{array}$ & 22 & Subsidiary + assembly units \\
\hline 8 & $\begin{array}{l}\text { Hydro-thermo sanitary } \\
\text { (valves and components) }\end{array}$ & 260 & 950 & $\begin{array}{l}\text { Innovation - quality - human resource } \\
\text { development- pre and postsales } \\
\text { services }\end{array}$ & 17 & $\begin{array}{l}\text { Representative office +trading } \\
\text { company }\end{array}$ \\
\hline 9 & $\begin{array}{l}\text { Engineering (paper, } \\
\text { cardboard, cellophane) }\end{array}$ & 35 & 114 & $\begin{array}{l}\text { Technology-productcustomizing - } \\
\text { service }\end{array}$ & 6 & Representative office \\
\hline 10 & Refrigeration rooms, plants & 120 & 750 & $\begin{array}{l}\text { Technology-specialization-quality- } \\
\text { design }\end{array}$ & 20 & WFOE +JV \\
\hline 11 & Food (pasta production) & 230 & 444 & Product quality, tradition +innovation & 13 & Directexports \\
\hline 12 & \begin{tabular}{|l} 
Automotive (high- \\
technology components)
\end{tabular} & 5000 & 28000 & $\begin{array}{l}\text { Technology and innovation - flexibility - } \\
\text { resource involvement }\end{array}$ & 14 & $3 W F O E+J V$ \\
\hline 13 & $\begin{array}{l}\text { Engineering (laser } \\
\text { machines and sheet metal) }\end{array}$ & 176 & 1400 & $\begin{array}{l}\text { Technology and innovation- niche } \\
\text { product- relations }\end{array}$ & 16 & $3 J \mathrm{Vs}+$ \\
\hline 14 & Carand industry tires & 4.100 & 29570 & $\begin{array}{l}\text { Technology - quality - relations with the } \\
\text { partners }\end{array}$ & 5 & JV +WFOE \\
\hline 15 & Food (rice production) & 110 & 137 & Technology-quality- investment in $R \& D$ & 12 & Directexports \\
\hline 16 & $\begin{array}{l}\text { Design and construction of } \\
\text { large plants }\end{array}$ & 1200 & in China 270 & $\begin{array}{l}\text { Organization- safety standards - } \\
\text { efficiency }\end{array}$ & 5 & WFOE (green field) \\
\hline 17 & Household pressed metal & 100 & 500 & Design - quality-global product & 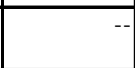 & $\begin{array}{l}\text { Directexports with a representative } \\
\text { office in Hong Kong }\end{array}$ \\
\hline 18 & Lighting engineering & 168 & 1217 & $\begin{array}{l}\text { Product quality- innovation-design- } \\
\text { human resources }\end{array}$ & 6 & WFOE \\
\hline 19 & $\begin{array}{l}\text { Special fertilizers (low } \\
\text { environmental impact) }\end{array}$ & 75 & 268 & Quality- investments in research & 8 & $\begin{array}{l}\text { Indirectexports +WFOE (acquired } \\
\text { companies) }\end{array}$ \\
\hline 20 & $\begin{array}{l}\text { Packaging and chemical } \\
\text { (cellulose acetate) }\end{array}$ & 2130 & 887 & Technologicaldevelopment-research & 20 & WFOE \\
\hline 21 & Aluminum finishing & 20 & 44 & $\begin{array}{l}\text { Technology- research and } \\
\text { development-quality }\end{array}$ & 20 & WFOE + Hong Kong subsidiary \\
\hline 22 & Rubberchemical & 44 & 170 & $\begin{array}{l}\text { Productrange -design - value for } \\
\text { money-relation }\end{array}$ & 7 & $\begin{array}{l}\text { Trade company + production platin } \\
\text { JV }\end{array}$ \\
\hline 23 & Engineering & 240 & 969 & $\begin{array}{l}\text { Fastdelivery times - research centers } \\
\text { and laboratories }\end{array}$ & 8 & Green field JV $(25 \%)$ \\
\hline 24 & Textile engineering & 26 & 78 & Niche product & 30 & Directexports +JV (assembly) \\
\hline 25 & Metallurgical & 16 & 76 & Product quality - production efficiency & 30 & JV (one of the first Italian in China) \\
\hline 26 & Chemical-cosmetic & 3.6 & 23 & $\begin{array}{l}\text { Product quality - post sales } \\
\text { assistance - innovation - flexibility }\end{array}$ & 2 & Export through intermediaries \\
\hline 27 & Electronic & 97 & 581 & Service, product quality, efficiency & 9 & Acquisition company branch \\
\hline 28 & Engineering (valves) & 132 & 700 & $\begin{array}{l}\text { Production costs, safety and quality } \\
\text { standards, research and development, } \\
\text { personalization }\end{array}$ & 5 & Acquisition of local businesses, JV \\
\hline 29 & Pneumatic automation & 93 & 384 & $\begin{array}{l}\text { Quality, innovation, flexibility, pre and } \\
\text { postsales service }\end{array}$ & 13 & $\begin{array}{l}\text { Subsidiary +assembly units + } \\
\text { acquisitions in other sec tors }\end{array}$ \\
\hline 30 & Engineering & 19 & 60 & $\begin{array}{l}\text { Innovation, quality and safety, } \\
\text { production flexibility }\end{array}$ & 2 & WFOE (production and assembly) \\
\hline 31 & $\begin{array}{l}\text { Engineering-automotive } \\
\text { filters and others }\end{array}$ & 230 & $\begin{array}{r}2800 \text { (2200 in } \\
\text { China) }\end{array}$ & $\begin{array}{l}\text { Quality - customerservice - technology- } \\
\text { investments in the Chinese market }\end{array}$ & 13 & WFOE with 4 factories \\
\hline
\end{tabular}




\section{FIGURES}

Figure 1: A strategic model for sustainable internationalization

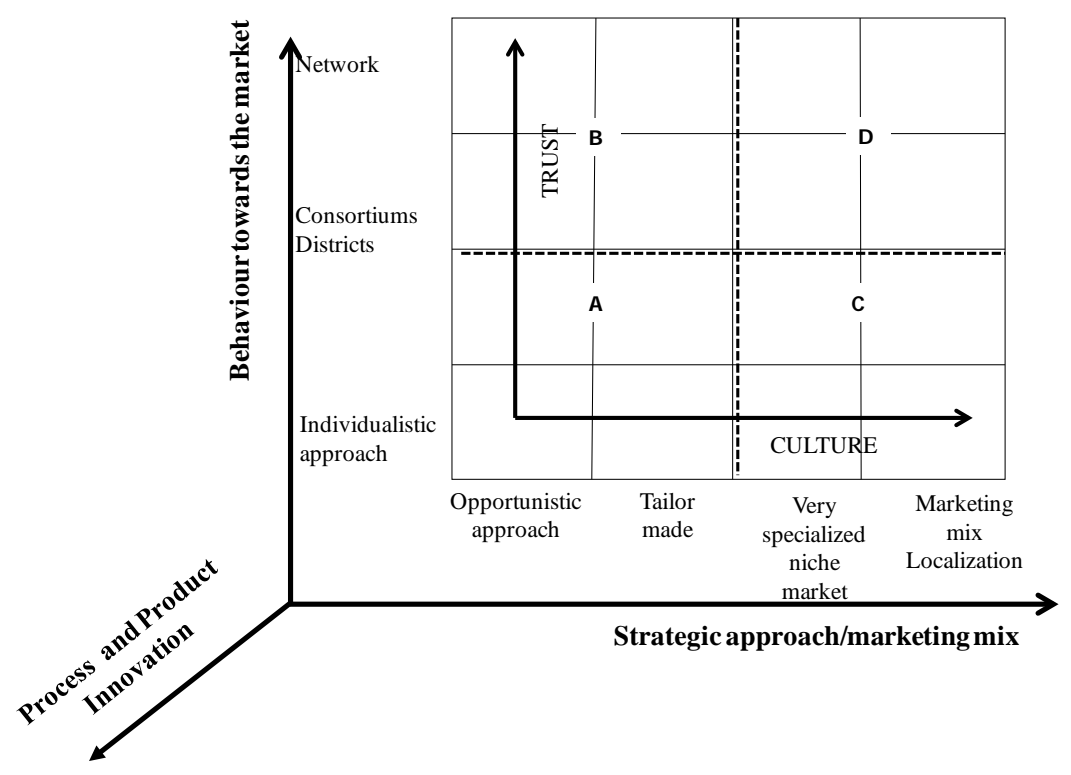

Source: adapted from Battaglia, Cedrola 2010

Figure 2: The positioning of the case studies

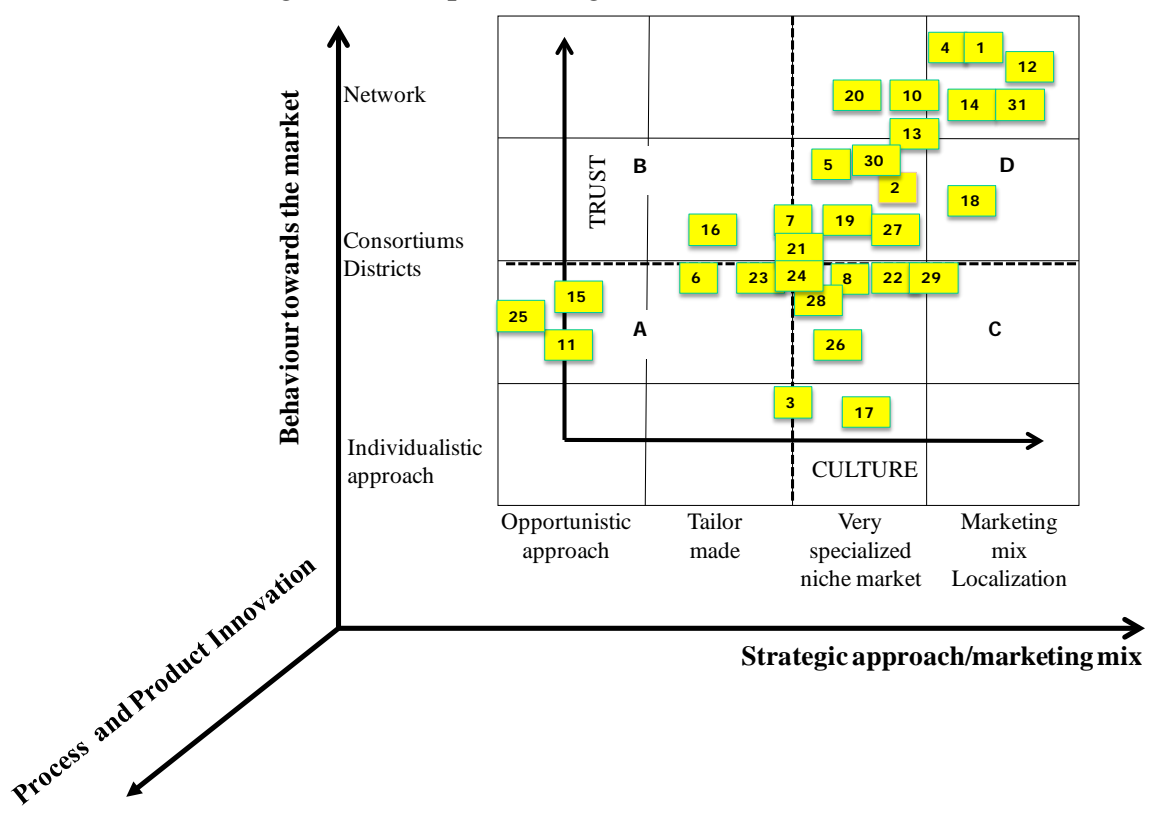

REFERENCES

Battaglia, L. and Cedrola, E. 2010. "Interazione culturale e processi di negoziazione”. In: Marketing e management interculturale. Attori, politiche e organizzazione. Eds. S. Guercini. Bologna: Il Mulino. 
Becchetti, R. and Gonzales, L. 2001. "Struttura proprietaria e accesso ai mercati esteri nelle piccole e medie imprese italiane”. In: Le imprese esportatrici italiane: caratteristiche, performance e internazionalizzazione. Eds. B. Quintieri. Bologna: Il Mulino.

Belussi, F. and Pilotti, L. 2006. "Eterogeneità delle imprese e varietà dei modelli organizzativi”. In: Organizzazioni, conoscenze, e sistemi locali. Eds. G. Cainelli and A. De Felice and N. De Liso. Milano: Franco Angeli.

Belussi, F. 2007. “Distretti e cluster verso nuove forme di agglomerazione territoriale di imprese”. In: Rileggere l'impresa. Relazioni, risorse e reti. Un nuovo modello di management. Eds. R. Fiocca. Milano: ETAS.

Belussi, F. and Sammarra, A. and Sedita, S.R. 2009. "Le nuove leve competitive dei sistemi locali tra apprendimento localizzato e reti traslocali”. In: Imprese e processi di internazionalizzazione. Eds. C. Pepe and A. Zucchella. Bologna: Il Mulino.

Bonaccorsi, A. 1992. “On the relationship between firm size and export intensity”. Journal of International Business Studies 23 (4): 605-635.

Bontempi, M.E. and Prodi, G. 2009. "Entry strategies into China: the choice between Joint Ventures and Wholly ForeignOwned Enterprises. An application to the Italian manufacturing sector”. International Review of Economics and Finance 18 (1): 11-19.

Cantù, C. and Gavinelli, L. 2008. "Reti di territorio: la valorizzazione delle risorse intangibili in un orizzonte internazionale”. In: Atti del Convegno Nazionale Aidea Giovani, University of Macerata (Italy), 25-26 gennaio.

Caroli, M. and Lipparini, A. Eds. 2002. Piccole imprese oltre confine. Competenze e processi di internazionalizzazione. Roma: Carocci.

Cavusgil, S.T. 1980. “On the internationalisation process of firms”. European Research 8 (6): 273-281.

Cedrola, E. 2005. Il marketing internazionale per le piccole e medie imprese. Milano: McGraw-Hill.

Cedrola, E. 2006. "Cooperation in small and medium enterprises to break into international markets - Angeli della Moda on the Japanese market”. In: Proceedings of Coordination and cooperation across organizational boundaries. Catholic University of Milan and London School of Economics and Political Science. Milan. 20-21 April 2006.

Cedrola, E. and Battaglia, L. and Tzannis, A. 2009. The Italian SMEs in the International context. A model to succeed in the global arena. Università di Macerata: Collana Quaderni del Dipartimento di Istituzioni Economiche e Finanziarie 52.

Cedrola, E. and Cantù, C. and Gavinelli, L. 2009. “Territorio, relazioni e competitività. Verso nuovi percorsi di sviluppo nazionale ed internazionale per le piccole e medie imprese italiane”. In: Proceedings of 8th International Congress Marketing Trends. Paris. 16-17 January.

Cerutti, C. and Delbufalo, E. 2009. "La gestione delle catene internazionali di fornitura: le sfide per le imprese italiane dei distretti moda”. In: Imprese e processi di internazionalizzazione. Eds. C. Pepe and A. Zucchella. Bologna: Il Mulino.

Chiarvesio, M. and Di Maria, E. 2009. “Innovazione, internazionalizzazione e ICT: l'impresa distrettuale italiana tra globale e locale”. In: Imprese e processi di internazionalizzazione. Eds. C. Pepe and A. Zucchella. Bologna: Il Mulino.

Compagno, C. 2003. “Aspetti di governance e processi di internazionalizzazione delle PMI”. Sinergie 60: 51-88.

De Burca, S. and Fletcher, R. and Brown, L. 2004. International Marketing. A SME Perspective. Australia: Pearson Education.

Dunning, J.H. 1988. "The eclectic paradigm of international production: a restatement and some possible extentions". Journal of International Business Studies 19 (1): 1-31. 
Erikson, K. and Johanson, J.A. and Majkgard, A. and Sharma, D. 1997. "Experiential knowledge and cost in internationalization process”. Journal of International Business Studies 15 (4): 337-360.

Etemad, H. 2004. "Internationalization strategies for small and medium sized-enterprises facing a typology of different competitive environments”. In: Handbook of international entrepreneurship. Eds. L.P. Dana. Cheltenham UK: Edward Elgar.

Ferragina, A. and Quintieri, B. 2001. “Caratteristiche delle imprese esportatrici italiane”. In Le imprese esportatrici italiane: caratteristiche, performance e internazionalizzazione. Eds. B. Quintieri. Bologna: Il Mulino.

Gallo, A. and Arino, A. and Manez, I. and Cappuyns K. 2002. "Internationalisation via strategic alliances in family business”. In: The future of family business: values and social responsibility. 13th FBN Annual World Conferenc. Eds. M. Koiranen and N. Karlsson. Helsinki.

Garofoli, G. 2003. "Distretti Industriali e processo di globalizzazione: trasformazione e nuove traiettorie”. In: Impresa e territorio. Eds. G. Garofoli. Bologna: Edizioni Istituto Tagliacarne Il Mulino.

Ghauri, P.N. and Usunier, J.C. 2003. International business and management series. Oxford, UK: Pergamon.

Harold, G. and Gankema, H. and Snuif, H. and Zwart, P. (2000). “The Internationalization Process of Small and Mediumsized Enterprises: An Evaluation of Stage Theory”. Journal of Small Business Management 38 (4): 15-28.

Herbig, P.A. 2003. Marketing Interculturale. Milano: Apogeo.

Hofstede, G. 2001. Culture's Consequences, Comparing Values, Behaviors, Institutions, and Organizations Across Nations. Thousand Oaks CA: Sage Publications.

Hostende, G. (1980). Cultural Consequences: International Differences. Work-Related Values. Beverly Hills: Sage.

Hymer, S.H. 1976. The. international operations of national firms: A study of direct foreign investment. Cambridge MA: MIT Press.

Johanson, J. and Vahlne, J.E. 1992. “Management of foreign market entry”. Scandinavian International Business Review 1 (3): 9-27.

Kostova, T. and Zaheer, S. 1999. "Organizational legitimacy under conditions of complexity: the case of the multinational enterprise”. Academy of Management Review 24 (1): 64-81.

Leonidou, L.C. and Katsikeas, C.S. 1996. “The export development process: an integrative review of empirical models”. Journal of International Business Studies 27 (3): 517-577.

Linder, B.S. 1961. An Essay on trade and transformation. Stoccolma: Almqvist \& Wiksel.

Madhok, A. 1997. "Cost, value e foreign market entry mode: the transaction and the firm”. Strategic Management Journal 18 (1): 39-61.

Marcone, M.R. 2005. Business Marketing e internazionalizzazione delle PMI italiane. In: Proceedings of 2nd Convegno annuale della Società Italiana Marketing, Trieste, 2-3 dicembre.

Mariotti, S. and Mutinelli, M. 2001. “L’internazionalizzazione delle piccole e medie imprese: lo scenario delle esperienze italiane”. Sinergie 13: 9-33.

Melin, L. 1992. “Internationalization as a Strategy Process”. Strategic Management Journal 13: 99-118.

Musso, F. 2006. “Strategie di internazionalizzazione fra economie distrettuali e filiere estese”. Sinergie 69: 61-85.

O’Grady, S. 1996. “The Psychic Distance Paradox”. Journal of International Business Studies 27 (2): $309-33$. 
Olhin, B. 1933. “Interregional and international trade”. Harvard Economic Studies. Cambridge.

Pepe, C. and Musso, F. 2009. "Piccoli produttori e grandi distributori: prospettive di sviluppo internazionale nei circuiti commerciali e logistici”. In: Imprese e processi di internazionalizzazione. Eds. C. Pepe and A. Zucchella. Bologna: Il Mulino.

Posner, M.V. 1961. International trade and technical change. Oxford Economic Papers.

Ricardo, D. 1817. (reprint 1981). The principles of political economy and taxation. Cambridge, U.K: Cambridge University Press.

Rullani, E. 2002. “Global-mente”. Economia e Politica Industriale 113: 19-46.

Rullani, E. 2006. “L’internazionalizzazione invisibile. La nuova geografia dei distretti e delle filiere produttive”. Sinergie 69: 3-32.

Ruzzier, M. and Antoncic, B. and Hisrich, R.D. 2007. “The internationalisation of SMEs: developing and testing a multidimensional measure on Slovenian firms”. Entrepreneurship \& Regional Development 19 (March): $161-183$.

Simon, H. 1996. Hidden champions: lessons from 500 of the world's best unknown companies. Boston Massachusetts: Harvard Business School Press.

Smith, A. 1776. (reprint 1963). An inquiry into the nature and causes of the wealth of nations. Homewood: Irwin.

Usunier, J.C. 1996. Marketing Across Cultures, London: Prentice Hall.

Usunier, J.C. and Lee, J.A. 2005. Marketing Across Culture, England: Pearson Education.

Varaldo, R. and Ferrucci, L. Eds. 1997. Il distretto industriale tra logiche di sistema e logiche di impresa. Milano: Franco Angeli.

Zanni, L. and Zucchella, A. 2009. "I nuovi imprenditori internazionali italiani. I casi delle imprese nate globali e dell'imprenditoria etnica nei distretti industriali”. In: Imprese e processi di internazionalizzazione. Eds. C. Pepe and A. Zucchella. Bologna: Il Mulino.

Zucchella, A. 2006. "Local clusters dynamics: trajectories of mature industrial districts between decline and multiple embeddedness”. Journal of Institutional Economics 2 (1): 21-44.

Zwart, P.S. and Gankema, H.G.J. 1990. “The export behaviour of SMEs in the Northern Part of The Netherlands”. Research Memorandum 393 van het Instituut voor Economisch Oderzoek. The Netherlands Groningen: University of Groningen. 